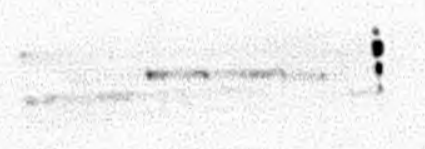

\title{
Pigures! AECD-4092
}

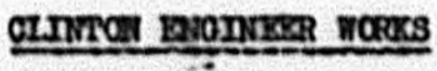

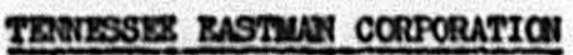

Contract No, N-7401-eng-23

\section{Dsveropinar prvisias}

Dr. C. 8. Lareon - Director

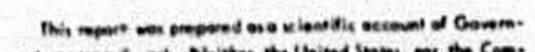

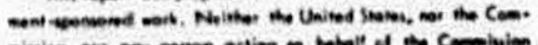

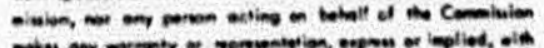

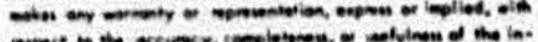

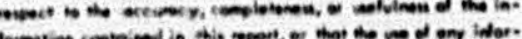

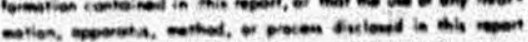

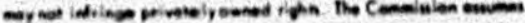

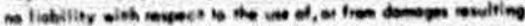

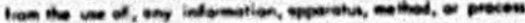
divelued in this apoert

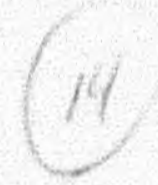




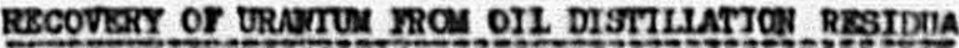

\section{ABSTRMOS}

The complete developmant of an ofrect: vo procese for recovery of tho uranian in the residues froed distillation of used Kinuey and diffualot puep o1la or alm lar o1le le desovibed. Arter eons dorablo study and experimentetion with several nethods, a sucoeserul procefure hes been dereloped The recomended procedure eabodien solution of the residuea in triohlorochylone followed by extraction with altedo ac1d, Recovery of uranium 1s botter than 99 pereont offective asd tho mothod nay be npplled directly to cortaminated ofla as woll ns to thelf alst:1lation residues. 


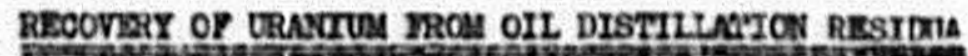

\section{MFrRODNCTICS}

The study of poasible mothode for the recovery of uranium froa Kinnoy and aifrusion puap 0ile, hes led to the ut121zation of vacuus distillation for the 1 solation of this substance is the dietillat1 on residues. The distllates, which are produced uraniun free, represent the bulk of the used ofla, epproxinateiy 90 to 97 . Although the greater poriton of the 011 is thus dec jntaninated and the uraniun 1s concentrated into a comparatively unall amount of dist1llation rea1dua, tho problem otill rotalns $1 \mathrm{t}$ orlginal corplexity in that it Involvee 1eolation of a minute anount of a motalle element from relativeiy large mases of organic material. The concentration of urenium in the d1stillation residues la usually of the order of $10 \mathrm{co}$. 100 nlerograns per gram, depending of course, upon the degree or contamination of the o1le before diat1llation.

The urantum present in the residues has been aseumed to bo uranyl ehloride for the following reasons. The olls wero most probably conteralnated originaliy by infileration of cherge material frop plent operatlons. Thls would introduce the tetrachloride, eubject to the conditions of bydrolysio and oxidation when the olls vero exposed to atmuspherle conditione prior to distilation. Further, the 011 s are suceserally purifled by distilation under the conditione of high racuum and elevated temperatures, Under these conditions, no simultaneous distillation of uraniun oould be detected. The ureniun rexaining in tho 
rea1due ahould consequently bo ubject to attack by effective abaorbenta or extracting egenta,

The actual experinentation eabraces severel pheses, Ineluding alkall adeorption, eolveat extraetion, etc ", but evecesaful recovery or the uraniua was achioved by diesolving the reeiduea in an Int ereediate eolrent, trichlorethylene, and waebing this wature with a utrie aois solution.

\section{ExpiznngreuL}

\section{Alka21 Masorption}

Sovaral atcemptes were made to romove urani us from those oll d1st1liation residua by adeorption with solid elkall and th some suceeve. The 012 realdues wore allowed to droin through colutine packed whth sodiua hydroxide pollets. The 011 wae reoyeled eoveral times, dopeading upon the length of the colume ueed. A typleal colurm consieted of a longth of $30-a 121$ notor glase tubling ritted with a stopeook at the lower and so that the rate of disobargo could be throttled to a mininua. Samples of o1l of different degrees of contanination and at room temperature were pasaed through these columns. Wth the equivalent of a ton-foot paes, tho semples were relleved of their urantun cont ont to the extent of roughly 80 percent. Maditionad paseos soened to be Idalted to recovery of uraniun down to approximately 8 to 10 parte per milion uraniun not rocovored, Experimente at elevated temeraturea ( steam-jacketed columns) givo similar but unimproved reoulto. The uraniun absorbed in the colume was renoved by plushing the alkall with dlethyl ether. Thls proceduro eeemed to bo effootl vo to a conalderable ortent and the calum could be roused after euch "regeneration" for a

$$
744-4
$$


Lated nuaber of tinea. The pellete eventually disintegrate, however, and the entire anes of the alkall hed to be reaoved and proceaeed for the restdual uraniua that it centalned.

Slace theae proseduree for alkell adevption are not ccapletely effective, exe complicated to adminioter and repul re excessive anount of reagents, It was decided to try aoae more couren1ent and probably more orfeotive mochod,

Consequently, thls phase of the oxperinentation wae discontluued and the work directed toward solvent extraetion. In the event that other, more sat1afactory nothode, couzd not be found for thie application, alkall edaorption coulc ot11 bo used as a last reaort. By first removine tho bulk of the contaninatl on by adsorytion with sol1d alkall, it would st1ll be expedient to 1 gnite the resaining ofl without exposing the greater part or the uranlun to the potent1al losess ineused by 1 enition. Solvent Ixtract1on

The poesibility of rezoving the uranium fron the 012 realduos by solvent extraction was investigated and attempts to do oo wore made with oeveral aolrente, Specifically, thac aclvent s wore: diethyl other, albutyl carbitol, trichlorothylene, and penta-other. Samplea or the 011 were dissolved; in theese eolvents at ratios varying frots 10 to 100 parte of solvent to 1 part 011. The mixture (01) and solvent) was then washed with water and the aqueous phase analyzed for the urantum tbat 1t had acquired.

In moet cases, const derable otulsislcatlon oceurred during at loast the first pass, or at beet, requirod covalderablo ties to settlo out. The degree of uranium recovery was not considered eatisfactory in any of the cases where direct solvent extraction was tried. 


\section{Nitrio Ao10 llaeb}

After unatiarectory results were obtalned by eolvent extraction nethode, It wes dectaed to observe the effect or acsd adution on these residua Semples of the 012, sonewhat alluted with dietbyl ether, trichlorethylene, or both, wore shaken nechenleally with nitrie ac1d at concentrations of 2 and 4 normal, Cursory analyel of the ac1d layoro bhowed that a very high degree of recovery had been achleved On the baelo of this Information an extensive survey wae Initiated to doternine accurately the effivavy of the proceduro and to deternine the cptimum conditionsnecessary for obtalning the hlgheat posatble degreo of revovery.

Preitminary teeto ahowed that adequate extraction could bo porforaed by a b-minuto ehak1ng perlod and this timo was adopted arbltrarlly for all eubeoquent toote. As a matter of aefety and oonvonleace, the of 1 seupleo woro disablred consistently in triehlorothyleno to provide ereater moblity and to prevent formation of culdelone during extract1on. The epecific strength of actd to be used was det orasned by a cortos of extrabtions perforaed with acid nornality as tho only rartablo, The resuits of these tests are ehown in Table I. Bach eample conet ated of $20 \mathrm{ml}$. From a typleal oll residue, disaolved in $50 \mathrm{ml}$. of triehlorethyiene and washed three t1mes in pasees or $100 \mathrm{ml}$, oach of the ald solution. The coebined aqueous phases from ech oxtraction wat analyzed for uranlua. 


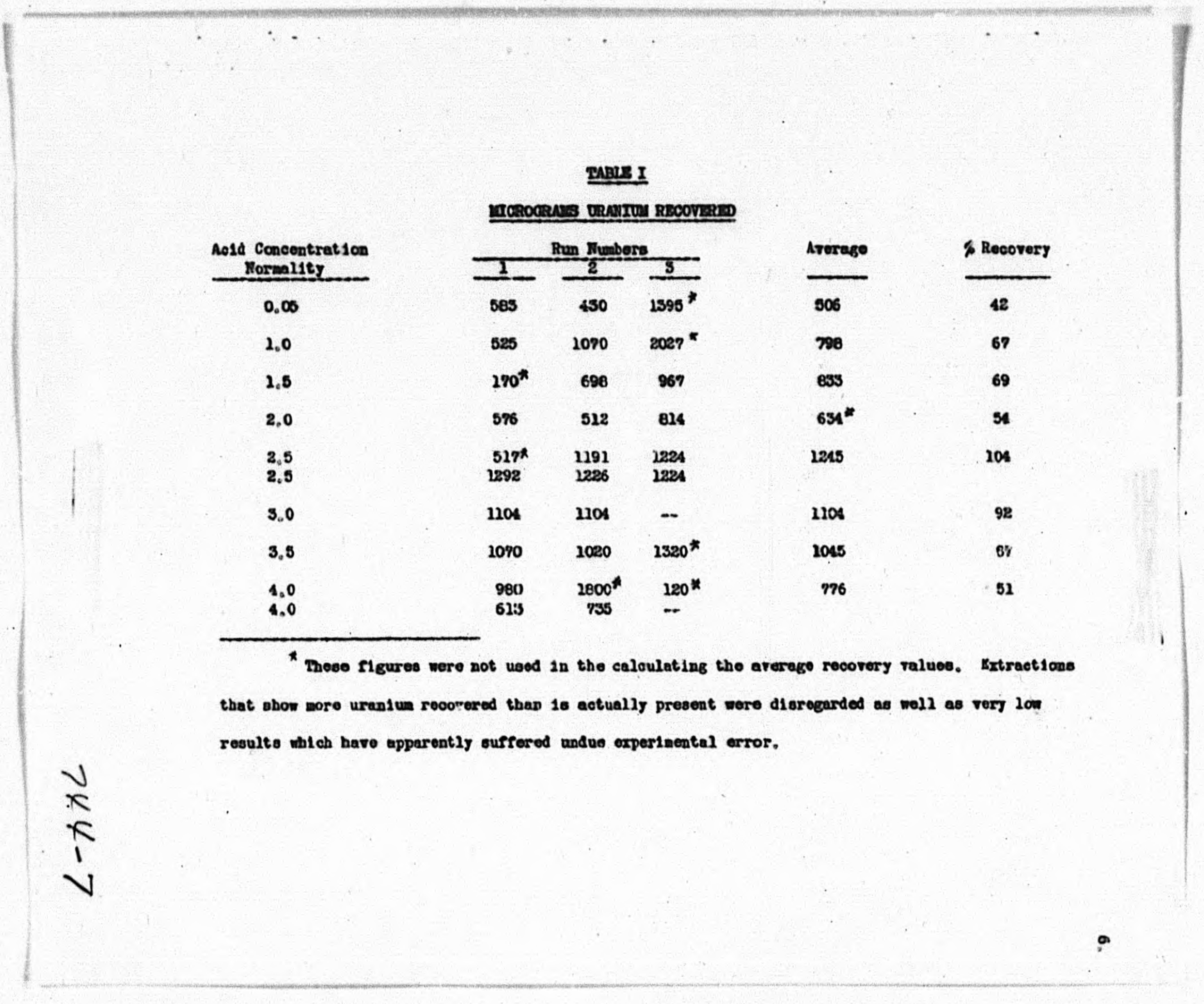


As can be observed in the above table, an aud concentration of 2.5 to 3.0 nornal proved to be the most sustable for offoctive extraction of the reasdues. Analysis of tho o1l residue used for the oxtraction in Table I shows that the uranlum concentration was 180 alcroCrans por gram (plua or minus ten merogrease), a figure which is in excellent agreement with the extraction reandte for 2,5 normal nitrie ac1d. The graph in rigure I will oerve to 111ustrate moro clearly the extraction efficiencles gained with the 2,5 norwal and other concentratione of vitrle eidd.

Analyole of the raffinate from extractions with 2.5 normal ac1d showe the residual uranlum content to be less than 1 microgreis per gram. The extraotions apparently yleld eseent1ally coaplete recovery of uranium rrom oll into nitrio asd Bolution.

Ertract Treatment

The information appearing in Table I was obtained from oxtractions conducted as previouely indicated but the nitric eold solution requires a vomenhat laborious treqtment in preparation of these eamples for urant um anelysis. The aqueous phase was ovaporated to drynese and rumod inth sulphuric and nitric aolds to destroy the small amounts of organic matter that were Invarlabiy Included as the result of the extraction. Iron was added and the uranium present co-frecipitated by an amonlum hydroxide prec1pitation. The washed precipitato was dsoolved in aulphurlo ao1d and electrolyzod. The eleotrolyte was then analyzed fluorometrically for uranlun.

Th1s prooedure served well onough to prepare samples for the ourvey. Samplea were prepared in tripllcate end the reoulte of all three tests, as rule, ohow remarkable egrecment, Regerdless of the success of 
this nethod, it waild obvieusly to lmpraotical for plast operatica. Sidee $2 t$ wad believed that theas ultrie aotd oolutiona eould be recorered of their diseolved uraniua by standard dstutyl onrbitol extrestion, in sptto of their organte content, It was deolded to that thl a particular tyge of aesapio.

Atceapte with seanples of ulatlar alze as Wose propared ror Tablo I yiolded positive reaulte but the agreenent was not eood; the extraction not being rully offoctive in all cases, Such behevior al ght be antloipated olnce those sampies did kot contain onough urnatun to offoutively extract with carbitod. Samples of richor-granlua eaitent. iere next propared by eveporating the extruet of 1 nreer agnle extracti ons and compared to efroctivenese of esirbitol extraction with the original Buple proparation method. The results or processing 50-nilliliter ofl residue samples with corresponding ratios of the preestbed rengents appear In Table II

\section{TAnLي II}

\section{TOPAL URAMIU RBCOVERED}

-111erame)

Procipltation
0,26
0,20
0,20
Averbods
Averago 0,22 or 0.2


The agreemetht show by these sarples of relatirely small rolume are belleved to be sufriclent eridence of the fact that extraote of the nature hereln described way be combined with similar salvage solutions (more concentrated material) and of foctively extracted by routine carbitol mathoda

A bas10, probable proceduro may bo dorined at thls polnt 0:1-dist1llation roeldue may be disoolved $2 \mathrm{n}$ four or P1vo times their rolume or trichlorethyloav and washed by conventional means wh th 2,5 normal nitrio asid eolutiun, effecting 99 percent recovory Tho oxtract solution my then be dispatched to the regular ohanne is for handilng ealvage solution by carbitol extraction, otc

\section{DIscussron}

The extrnction procedure dereloped as herein presented provides a elnal step 10 a process for resovery or uranium 'particulariy in microgram coacentracion) from vacuun pump 012.8. The treatment upplios epecifically to the diet1llation residua or st11l bottoms from the reclamation by vacuum distilation of Kinney and diffusion pump o12s. The whole procedure 18 comperatively eluple to administer, requiring as reagents only dilute nitric ecid ard trichloretbylege Added economy 18 obtalned becaues of the fact that both of these reagents may be recyoled with ooly small losses The oraporator conconsate from concenEration of the aitric aold wash may be roueve arter only a emall adjust. ment in aoldity and the low Jolligg point and high rapor pressure of trichlorethylene make it particularly practical to atrip this eolvent at atmospheric pressure and recycle as resieus diluent 


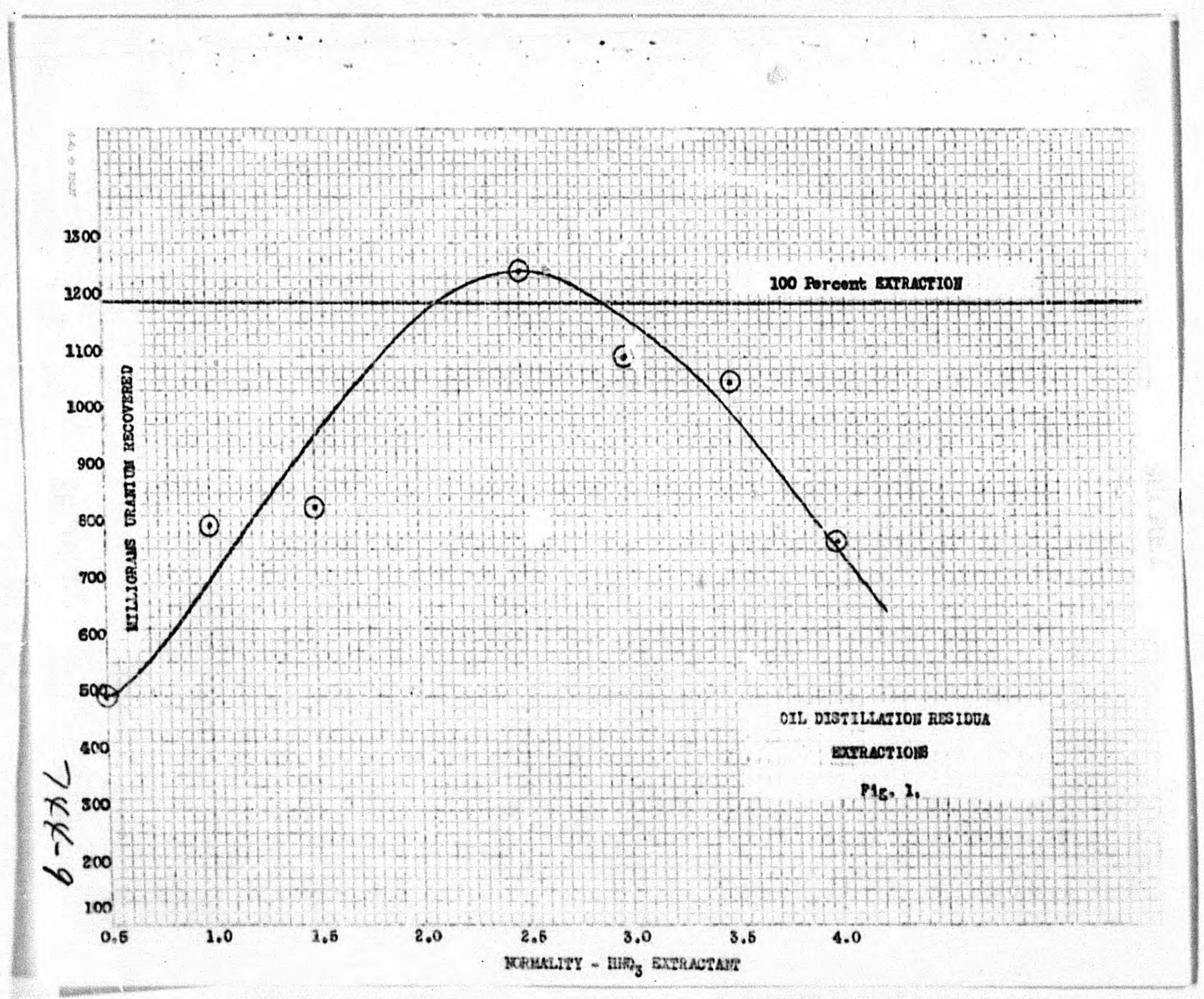




\begin{abstract}
Application of this procese could be ande alrootly to these 012s or sinilar alle without prollninery dist1llation to reolale tho 012 as rousablo distillate and to conoentrate the contarinant. Such applloation al ght be practical in case the rolumo of o1l to be extrected wae comparativoly onall and when it would not bo neoseseary to roolale the material approxleating the original flusd.
\end{abstract}

\title{
gonerar \\ vaporimentation undertaken to develop a procoes for the
} rocovery of uranium in o1l-distillation reeldua produced by the roclamation by vacuun distillation of $x$ inney and diffuel on punp oils and rolated mater1als. Recovory of alkall absorption and solvent extraction wore tried but the results of these experiments were uneatisfactory. Nitzie

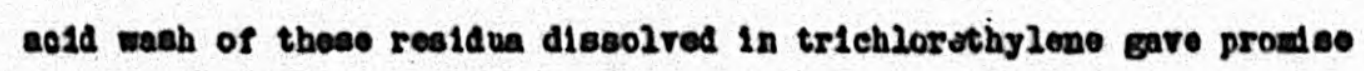
of ylolding adequate recovery and the work was dirested toward dovelopIng an optinum procedure. A rinal proceduse utilizing these reagents 18 prescribed and ylolde satiefactory recovery of uranium as ahow by the comparieon of analysie of extract, Inltial residue and raffinate. 


\section{ACXMOILEDERERTS}

Sgt. X. O, Hambrook to to be aroditad for substantial ooztributions to the exporimontation reported in this paper. doparture boforo ocmpletion of the work makes It imposeible to inolude his olgnature.

JsL/mo
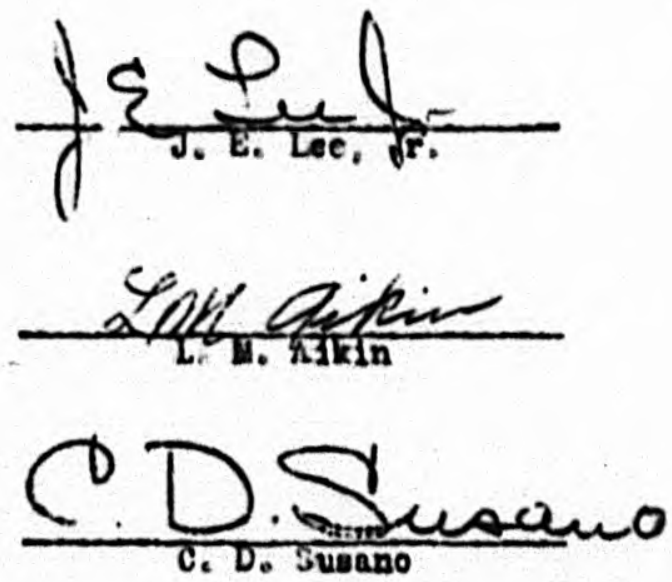

Dato Submittod 2-24-47

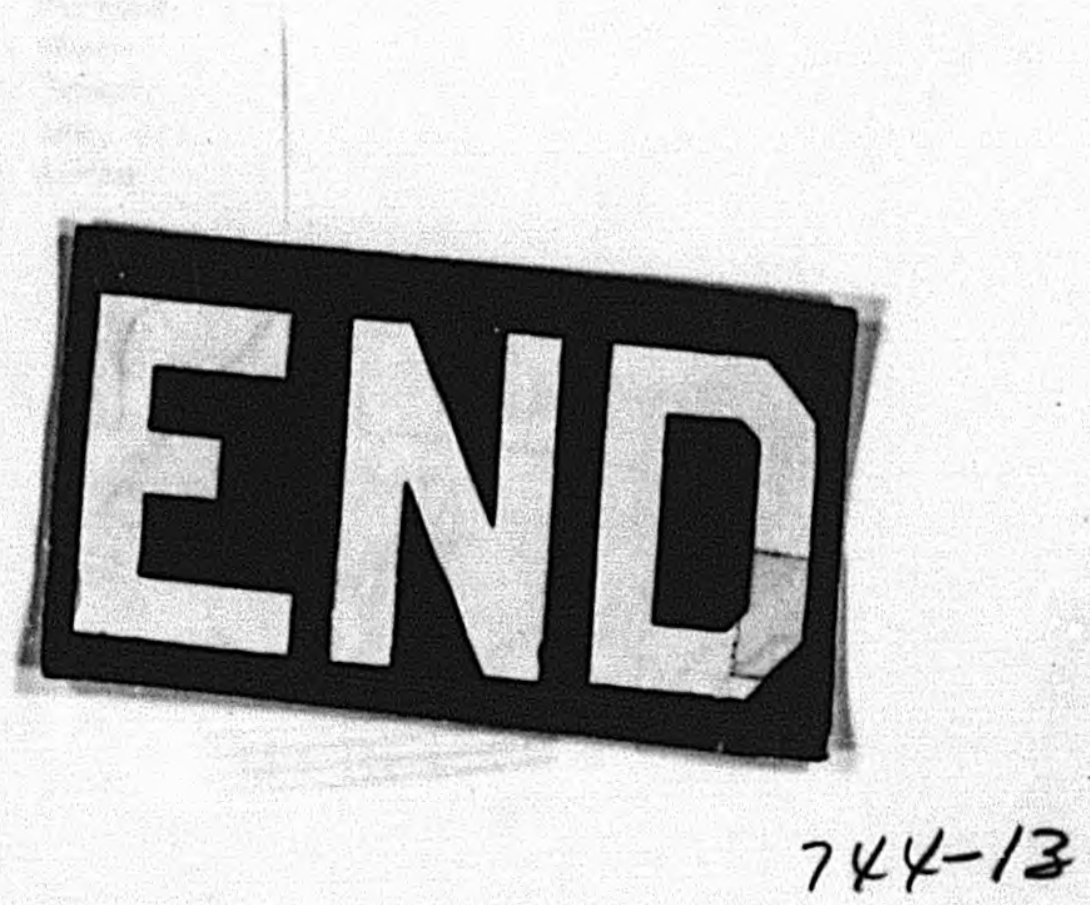

